\title{
Biological associations of color variation in the Indo-Pacific swimming crab Charybdis hellerii
}

\author{
TIMOTEO T. WATANABE ${ }^{1}$, FERNANDO J. ZARA ${ }^{2}$, GUSTAVO Y. HATTORI ${ }^{1}$, \\ ALEXANDER TURRA ${ }^{3}$ and BRUNO S. SANT'ANNA ${ }^{1}$ \\ ${ }^{1}$ Programa de Pós-Graduação em Ciência e Tecnologia para Recursos Amazônicos (PPGCTRA), \\ Universidade Federal do Amazonas (UFAM), Instituto de Ciências Exatas e Tecnologia (ICET), \\ Rua Nossa Senhora do Rosário, 3863, 69103-128 Itacoatiara, AM, Brasil \\ ${ }^{2}$ Universidade Estadual Paulista (UNESP), Faculdade de Ciências Agrárias e Veterinárias, \\ Centro de Aquicultura, Instituto de Estudos Avançados do Mar, Departamento de Biologia \\ Aplicada, Laboratório de Morfologia de Invertebrados, Campus de Jaboticabal, Via de Acesso \\ Prof. Paulo Donato Castellane, s/n, 14884-900 Jaboticabal, SP, Brasil \\ ${ }^{3}$ Universidade de São Paulo (USP), Instituto Oceanográfico (IOUSP), Departamento de Oceanografia \\ Biológica (DOB), Praça do Oceanográfico, 191, 05508-120 São Paulo, SP, Brasil
}

Manuscript received on September 26, 2013; accepted for publication on July 29, 2014

\begin{abstract}
A marine biological invasion is a natural process accelerated by human activities, and the crab Charybdis hellerii is an example of a globally widespread invasive species. This study evaluated color variation in $C$. hellerii and its relationship to the sex, size and sexual maturity of these crabs, and compared the efficiency of a freeware digital image-editing program with a commercially available program. The color of the individuals was analyzed using standardized digital images. The color pattern varied significantly with size; smaller and immature individuals were darker than larger and mature ones. The female abdomen changed in morphology and color with sexual maturity, becoming wider and orange-colored. There was no statistical difference in the color values between males and females and immature males did not show morphological or color differences in their abdomen. This study highlights the possible relationships of the color and physiological state of the reproductive system, which could help in future studies of behavior, avoiding the need to dissect and/or remove individuals from nature for assessment of sexual maturity. The freeware program showed the same efficiency in digital image analysis as a widely known commercial program.
\end{abstract}

Key words: Brachyura, coloration variation, digital image, Portunidae.

\section{INTRODUCTION}

Invasive species may cause environmental impacts, by competing for resources such as space or food, with native species, or predating on native species (Vitousek et al. 1997). Globalization and intense

Correspondence to: Timoteo Tadashi Watanabe

E-mail: timoteotw@gmail.com commercial traffic of ships and products may provide pathways for the introduction of non-indigenous species (Ruiz et al. 1997, Kerckhof et al. 2007). A well-known example is the Indo-Pacific portunid swimming crab Charybdis hellerii (A. MilneEdwards 1867), which is now found in different regions around the world (Sant'Anna et al. 2012b). 
In crustaceans, morphological variations are used to study differences between sexes, reproduction and behavioral strategies, and sexual maturity, among other traits (Detto et al. 2004, Hemmi et al. 2006, Pinheiro and Taddei 2000, Reid et al. 1997). For instance, some freshwater shrimps have a caste structure that may play an important role in their social system, since they have different morphotypes, each of which show a different behavior, size and phenotypic color pattern (Kuris et al. 1987, MoraesRiodades and Valenti 2004). For Brachyura, the variations in external morphology such as size and color are intraspecific, as observed in the semaphore crab Heloecius cordiformis (H. Milne Edwards 1837), which shows a relationship among the body size, claw size, and claw growth. The color of the claws also serves as a strong signal for mating and aggressive behavior (Detto et al. 2004). Similarly, the common spider crab Libinia emarginata Leach 1815 shows differences in general appearance, such as the chelipeds, which are associated with reproductive fitness in males (Laufer et al. 1994).

The phenotypic trait of exoskeleton color may vary in brachyurans, and also responds to different factors such as the molt cycle (Kennedy and Cronin 2007, Smith and Chang 2007), predation, i.e. cryptic or camouflage colors (Hemmi et al. 2006, Hultgren and Stachowicz 2008), microhabitat use (Trivedi and Vachhrajani 2012), salinity, desiccation and carapace thickness (Reid et al. 1997, Styrishave et al. 2004), temperature (Silbiger and Munguia 2008) and sexual maturity (Pinheiro and Taddei 2000). In contrast, no relationship to carapace color and ovarian development was found for the mangrove crab Ucides cordatus (Linnaeus 1763) (Castilho et al. 2011).

Most of these studies regarding color changes were conducted with individuals out of the water, and the air has a different relationship to light refraction, as distilled water and sea water have natural light-absorption properties (Morel 1974, Sullivan 1963). The effect of water changes even more if we consider the plankton and organic matter present in estuary and sea water (Bricaud et al. 1981, 1998, Doxaran et al. 2006). The variation in colors may be related to color perception. Portunids can perceive a range of wavelengths from 400 to $600 \mathrm{~nm}$ (violet to orange), with a peak at $500 \mathrm{~nm}$ (Croning and Forward Jr 1988). They usually live underwater in various depths and water types (estuary or open ocean), and the wavelengths refracted in the water could still be perceived and would not be absorbed at the depths where portunids are usually found (Aguilar et al. 2005, Clarke and James 1939).

Charybdis hellerii is a key species with several traits that favor invasions (Dineen et al. 2001, Sant'Anna et al. 2012b). The exoskeleton color has not been studied in this species, and only one study of this nature has evaluated a congener, the banded-leg swimming crab Charybdis annulata (Fabricius 1798) (Trivedi and Vachhrajani 2012). This study aimed to determine if the exoskeleton color variation of $C$. hellerii is related to crab maturity and size in males and females. Additionally, we evaluated the efficiency of a freeware digital image editing program, compared to a commercially available program that has previously been used for crabs (Casariego et al. 2011) and plants (Singh et al. 2011).

\section{MATERIALS AND METHODS}

\section{FIELD SAMPLES}

Portunid crabs were collected in July 2011, on the rocky shores of Ponta da Praia Beach (23 59' 28.9" S; $46^{\circ} 18^{\prime} 17.0^{\prime \prime} \mathrm{W}$ ) and Ilha Porchat Beach (23 59' 25.6" S; 46 22' 14.8' W), located on São Vicente Island, state of São Paulo, Brazil (Fig. 1). Two people manually collected the crabs for twohour periods at low tide for six days. All crabs were carefully packed in plastic bags and taken to the laboratory, where they were identified according to Lemaitre (1995) and Wee and Ng (1995) and anesthetized by thermal shock for the laboratory 


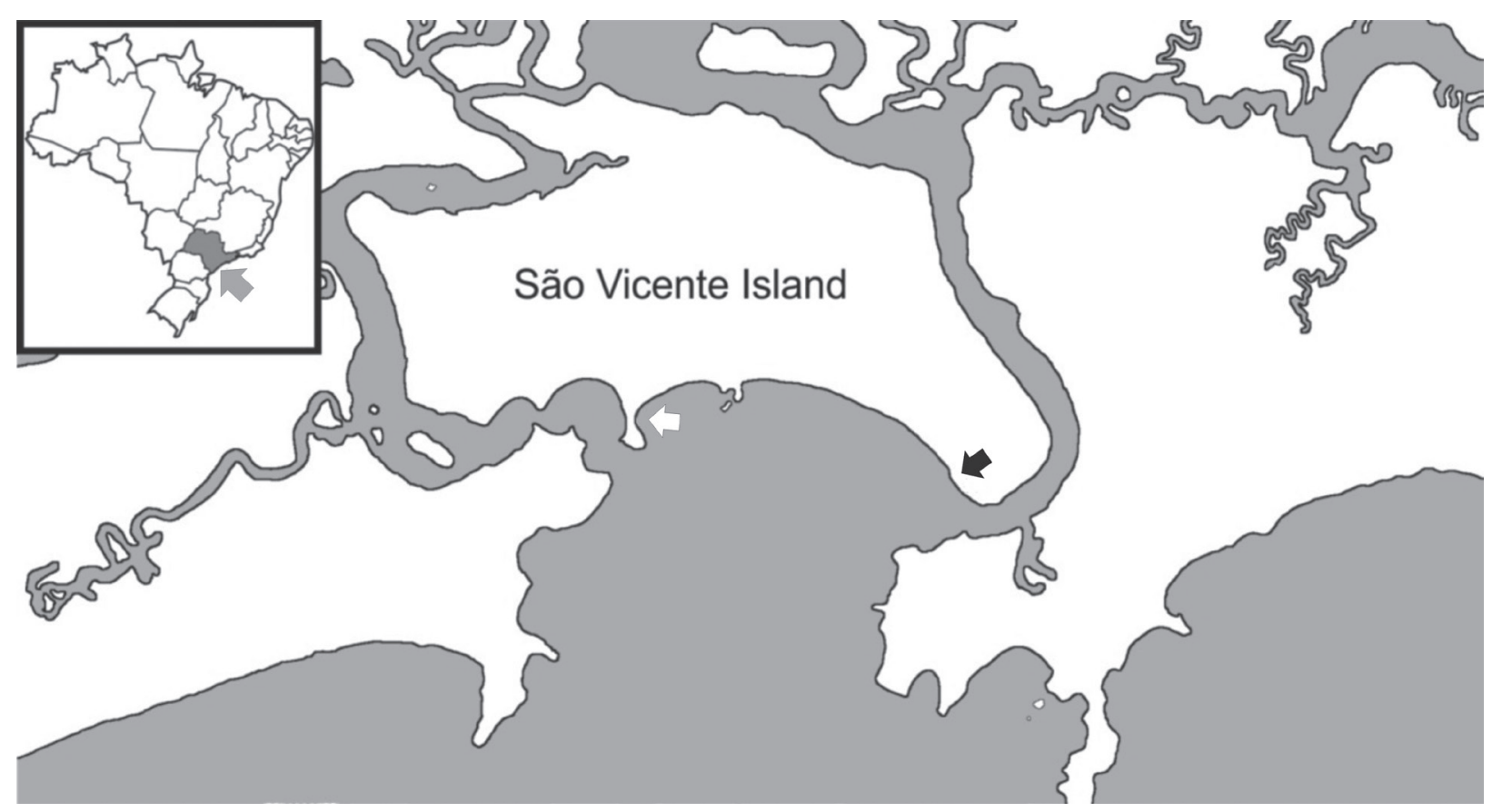

Figure 1 - Location of the sampling areas, Ponta da Praia Beach (black arrow) and Ilha Porchat (white arrow) in the estuary-bay complex of São Vicente Island, state of São Paulo (gray arrow), Brazil.

procedures. The carapace width was measured using calipers $(0.01 \mathrm{~mm})$, and the sex was determined by inspection of abdominal morphology. Sexual maturity was determined through inspection of the abdomen: adhered for juveniles or loose for adults. Sexual maturity was also determined through evaluation of the development of the reproductive system and gonads (sperm production for males and macroscopic ovarian stage for females, as in Sant'Anna et al. 2012a, b). The molt stages of the individuals were also recorded, and only individuals in the intermolt stage with a hard carapace were used in the analysis. All procedures were carried out according to the international practices for animal use and care under the control of an internal committee of the Universidade Estadual Paulista "Júlio de Mesquita Filho", Brazil.

\section{IMAGE ACQUISITION AND COLOR ANALYSIS}

The individuals were photographed using a Sony Alpha DSLR-A200 camera with an 18-55 mm lens. The camera was placed in a fixed standard position
(30 cm high) with fixed illumination by two lamps (20W fluorescent) behind a refractory surface, in order to avoid reflections. To standardize the error of image brightness, the camera was set to capture the images with a white balance adjusted to $5500 \mathrm{~K}$ color temperature, with no additional color filter, and an x-sync shutter speed of 1/60 s. The crabs were dried with a cloth and placed on an opaque white surface with adjusted value of 200 of red, green and blue, to photograph the carapace, chelipeds (internal and external surface), abdomen and pereopods, to evaluate the color variation. Each picture was converted to values of R, G and B individually for comparison. The values were taken from a histogram plot obtained from the selected area (the same area for all crabs, for each body structure) provided by the software used.

The digital images were analyzed in the free software GIMP (GNU Image Manipulation Program, USA), using the RGB (red, green and blue) values (minimum 0 , maximum 255) color mode, and the selected body structure, giving the 
average color values from a histogram plot that the program provides. The maximum value in the three colors represents white and 0 black, and the other colors (RGB) are the interaction of the values of these three individual colors (red, green and blue). The values of $R, G$ and $B$ individually were used for the comparisons.

\section{SOFTWARE COMPARISON FOR COLOR INVESTIGATION}

The freeware program (GIMP) and a commercially available program (Adobe Photoshop ${ }^{\circledR}$ ) were compared. A free trial was carried out to assess if the free program has the same analysis power as a commercial program, and if there were differences between them. For this purpose, the carapace RGB mean color spectrum of 40 randomly selected individuals was analyzed in both programs.

\section{STATISTICAL ANALYSIS}

The value of each color spectrum (red, green and blue) from each body structure (carapace, internal and external surfaces of chelipeds, and pereopods) was compared with a two-way analysis of variance (ANOVA); the factors were sex (male or female) and sexual maturity (juvenile or adult) (Underwood 1997). A linear regression using the size of the body structures of males and females and logarithmized mean values of the color (red, green and blue) was carried out and tested with the $F$ test. The $t$ test was used to compare the RGB values of the two programs. A significance level of 5\% was adopted for all statistical analyses (Sokal and Rohlf 1995), followed by the Bonferroni correction (Abdi 2007).

\section{RESULTS}

For all body structures analyzed for both sexes, the red color spectrum had the highest value and the blue color the lowest (Fig. 2). The carapace exoskeleton color differed significantly between sexually immature and mature crabs of both sexes, in all colors. However, only the blue color differed significantly between the sexes for the pereopods, and the interaction of the factors was not significant (Table I). The chelipeds also showed a significant difference for the stage of sexual maturity for both sexes, and no difference for the interaction of the factors (Table II). However, the data for the abdomen indicated significant differences for the sexes only for blue, and maturity for red, and for the interaction of the tested factors for all colors (Table III). Therefore, mature individuals have higher color values, but there were no differences between the sexes, only for the abdomen considering the interaction of the two factors.

Visually, the color of $C$. hellerii showed an increase in red/orange following the size increase, mostly on the chelipeds. The female abdomen showed three different morphotypes: closed white abdomen (juvenile), closed orange-colored abdomen (juvenile) and free orange-colored abdomen (mature); however, the male abdomen showed neither morphological nor color differences (Fig. 3). The visual observation of the color changes with size (Fig. 3) was corroborated by the results of the regression analysis for both females and males (Figures 4, 5 and 6). The regression comparing the size of individuals with the color values showed a significant relationship with the carapace color for all spectra for both sexes, and for the external surface of the cheliped except for the blue color of the females, as both showed an increase in color values with crab size; while there was no significant relationship for the internal surface of the cheliped and pereopods. For the female abdomen, the blue color decreased significantly with the size of the individuals; while for the males, there was no statistical difference for any color. In addition, the color changed progressively in relation to crab size: the female abdomen showed a juvenile morphotype, a juvenile pre-adult pubertal morphotype, and the adult morphotype (Fig. 3), indicating a relationship to the sexual maturity of the female. The comparison between the programs showed that the free program (GIMP) performed equally as well as the commercial program (Adobe ${ }^{\circledR}$ Photoshop $\left.^{\circledR}\right)(t=-0.0211 ; \mathrm{DF}=1 ; P=0.9832)$. 

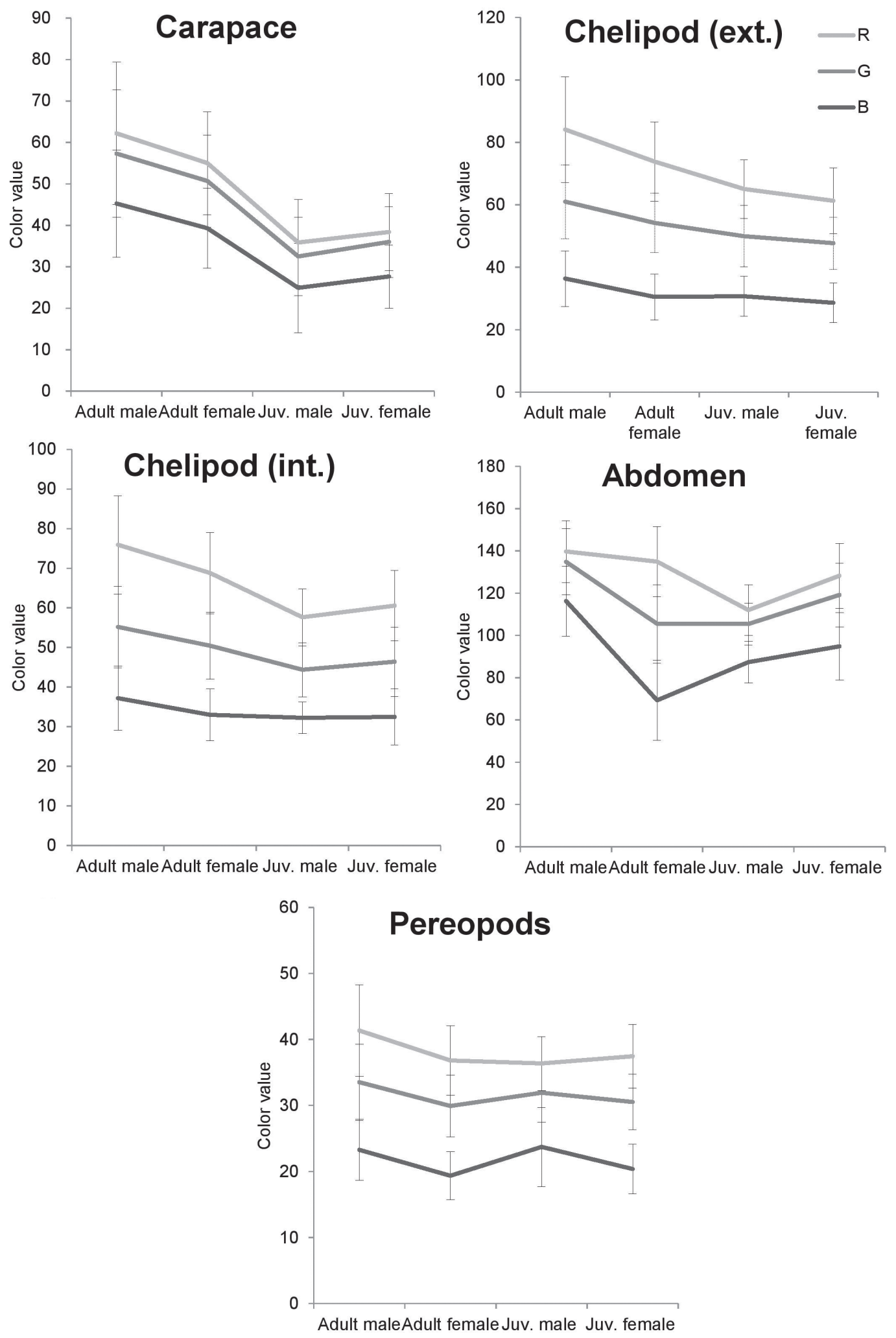

Figure 2 - Mean and standard deviation of color values (red, green and blue) for body structures of Charybdis hellerii (Maximum color value: 255). External surface=ext.; Internal surface=int.; Juvenile=Juv. 
TABLE I

Comparison of the carapace and pereopods of Charybdis hellerii with the color spectra (RGB, red, green and blue) by two-way ANOVA; the first factor is the sex and the second is sexual maturity. $\mathrm{DF}=$ degrees of freedom, MS = mean square, $F=F$ test value, $*=P<0.0125$ (Bonferroni correction).

\begin{tabular}{|c|c|c|c|c|c|c|c|c|c|}
\hline & \multirow{2}{*}{ Factors } & \multicolumn{4}{|c|}{ Carapace } & \multicolumn{4}{|c|}{ Pereopods } \\
\hline & & DF & MS & $F$ & $P$ & DF & MS & $F$ & $P$ \\
\hline \multirow{3}{*}{$\stackrel{n}{0}$} & Sex & 1 & 29.93 & 0.1928 & 0.6608 & 1 & 68.73 & 2.964 & 0.0861 \\
\hline & Maturity & 1 & 4055.99 & 26.1307 & $0.0000^{*}$ & 1 & 3.01 & 0.130 & 0.7187 \\
\hline & Sex x Maturity & 1 & 252.15 & 1.6245 & 0.2034 & 1 & 24.81 & 1.070 & 0.3017 \\
\hline \multirow{3}{*}{$\begin{array}{l}\mathscr{Q} \\
\simeq\end{array}$} & Sex & 1 & 66.03 & 0.3214 & 0.5711 & 1 & 32.10 & 0.894 & 0.3451 \\
\hline & Maturity & 1 & 5028.92 & 24.4770 & $0.0000^{*}$ & 1 & 52.38 & 1.459 & 0.2280 \\
\hline & Sex x Maturity & 1 & 242.90 & 1.1822 & 0.2777 & 1 & 84.44 & 2.352 & 0.1261 \\
\hline \multirow{3}{*}{ 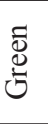 } & Sex & 1 & 31.12 & 0.1887 & 0.6642 & 1 & 65.73 & 2.514 & 0.1138 \\
\hline & Maturity & 1 & 4241.90 & 25.7280 & $0.0000^{*}$ & 1 & 2.33 & 0.089 & 0.7656 \\
\hline & Sex x Maturity & 1 & 267.22 & 1.6208 & 0.2039 & 1 & 13.66 & 0.522 & 0.4703 \\
\hline \multirow{3}{*}{$\stackrel{\stackrel{\Xi}{\Xi}}{\oplus}$} & Sex & 1 & 29.40 & 0.2441 & 0.6216 & 1 & 139.72 & 8.173 & $0.0045^{*}$ \\
\hline & Maturity & 1 & 2759.63 & 22.9122 & $0.0000^{*}$ & 1 & 6.55 & 0.383 & 0.5362 \\
\hline & Sex x Maturity & 1 & 201.83 & 1.6757 & 0.1964 & 1 & 1.20 & 0.070 & 0.7913 \\
\hline
\end{tabular}

TABLE II

Comparison of the chelipeds (external and internal surface) of Charybdis hellerii with the color spectra (RGB, red, green and blue) by two-way ANOVA; the first factor is the sex and the second is sexual maturity. DF = degrees of freedom, MS mean square, $F=F$ test value, ${ }^{*}=P<0.0125$ (Bonferroni correction).

\begin{tabular}{|c|c|c|c|c|c|c|c|c|c|}
\hline & \multirow{2}{*}{ Factors } & \multicolumn{4}{|c|}{ Cheliped (external) } & \multicolumn{4}{|c|}{ Cheliped (internal) } \\
\hline & & DF & MS & $F$ & $P$ & DF & $\mathrm{MS}$ & $F$ & $P$ \\
\hline \multirow{3}{*}{$\underset{己}{0}$} & Sex & 1 & 283.7 & 2.589 & 0.1087 & 1 & 35.5 & 0.465 & 0.4957 \\
\hline & Maturity & 1 & 951.7 & 8.686 & $0.0034^{*}$ & 1 & 638.7 & 8.365 & $0.0041 *$ \\
\hline & Sex x Maturity & 1 & 65.2 & 0.595 & 0.4412 & 1 & 134.7 & 1.764 & 0.1852 \\
\hline \multirow{3}{*}{$\begin{array}{l}\mathscr{Q} \\
\simeq\end{array}$} & Sex & 1 & 521.7 & 2.497 & 0.1152 & 1 & 47.0 & 0.384 & 0.5362 \\
\hline & Maturity & 1 & 2658.3 & 12.725 & $0.0004 *$ & 1 & 1873.7 & 15.306 & $0.0001 *$ \\
\hline & Sex x Maturity & 1 & 111.0 & 0.531 & 0.4667 & 1 & 270.0 & 2.206 & 0.1386 \\
\hline \multirow{3}{*}{ 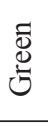 } & Sex & 1 & 216.5 & 1.990 & 0.1594 & 1 & 19.5 & 0.225 & 0.6359 \\
\hline & Maturity & 1 & 827.5 & 7.608 & $0.0062 *$ & 1 & 587.4 & 6.753 & $0.0098 *$ \\
\hline & Sex x Maturity & 1 & 55.4 & 0.509 & 0.4760 & 1 & 123.1 & 1.416 & 0.2351 \\
\hline \multirow{3}{*}{$\stackrel{\mathscr{m}}{\Xi}$} & Sex & 1 & 169.50 & 2.684 & 0.1024 & 1 & 42.00 & 0.786 & 0.3759 \\
\hline & Maturity & 1 & 150.72 & 2.387 & 0.1235 & 1 & 80.24 & 1.502 & 0.2212 \\
\hline & Sex x Maturity & 1 & 38.23 & 0.605 & 0.4371 & 1 & 51.40 & 0.962 & 0.3273 \\
\hline
\end{tabular}

\section{DISCUSSION}

The images of $C$. hellerii available around the world usually show a red or orange color (Wee and $\mathrm{Ng}$ 1995, Vannini and Innocenti 1999, Yokes and Galil 2006); in this study, the crabs showed a red, brown or greenish color. This could explain the high values of red color and the low values of blue color for all parts shown in the present study. Crustaceans show several agonistic behaviors related to the social organization, and sometimes have triggers to display these behaviors (Kuris et al. 1987, Warner 1970, Innocenti et al. 2003). This color variation, with differences mostly between adult males, adult females and the juveniles, 

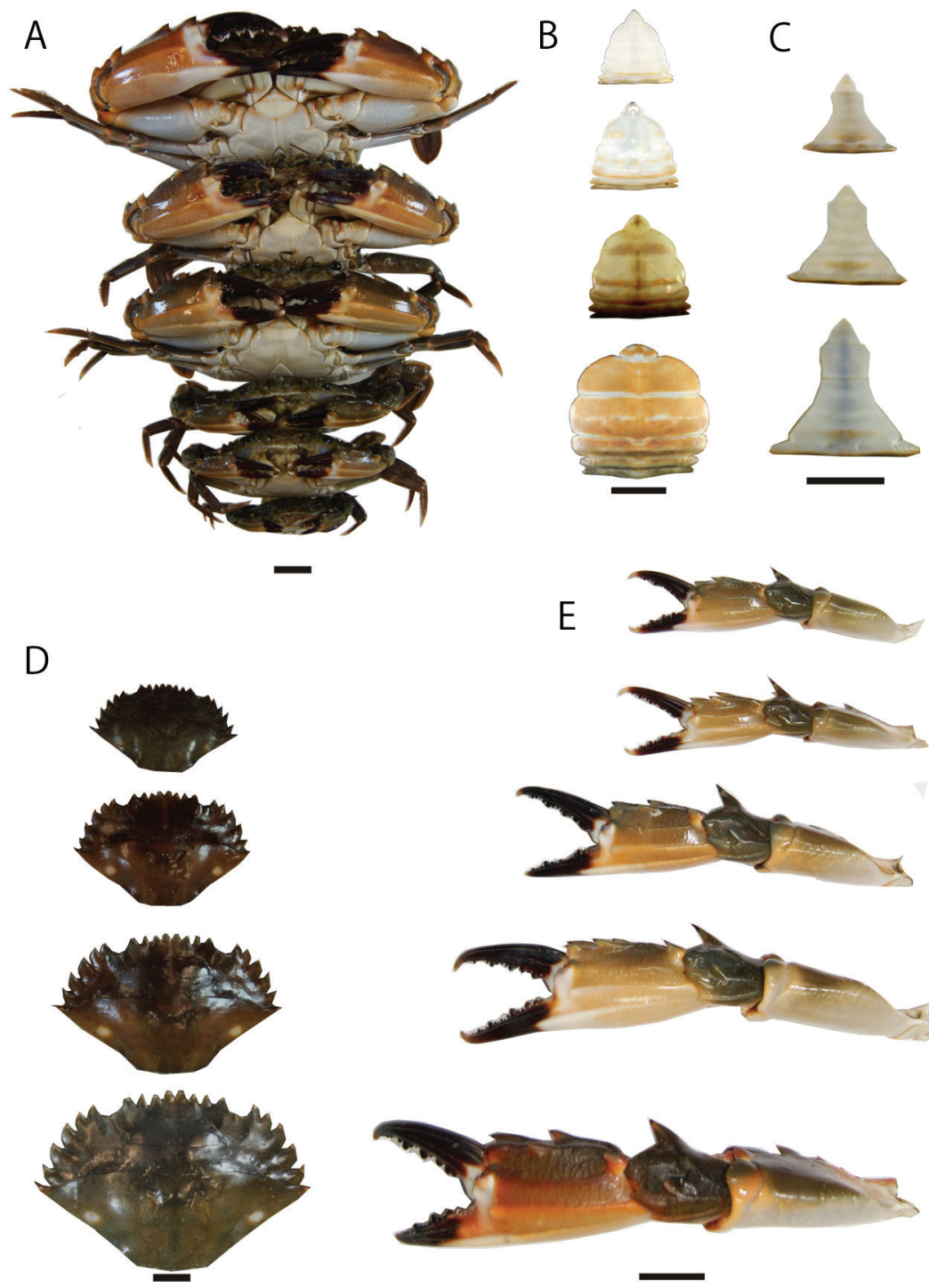

Figure 3 - Visual color variation of Charybdis hellerii related to carapace size and female sexual maturity (abdomen). Scale bar $1 \mathrm{~cm}$. A) Crabs; B) Female abdomen; C) Male abdomen; D) Carapace; and E) Chelipeds.

may indicate a relationship to social organization of this species, similar to those described for other crustaceans such as the mottled shore crab Pachygrapsus transversus (Gibbes 1850) (Abele et al. 1986) or the giant river prawn Macrobrachium rosenbergii (De Man 1879) (Karplus et al. 1992). The color variation may also be related to the individual size, as described for varunid crabs (Casariego et al. 2011).
The predominance of the color and size variation on the chelipeds is well known for male crabs, who display aggressive behavior toward other males and also use their major cheliped to attract females, as widely recorded for species of Uca (Crane 1966, Christy and Salmon 1984). In portunid crabs, although $C$. hellerii is slightly heterochelous (Figure 3), the difference between the left and right claw is not as evident as it is Uca spp. 
TABLE III

Comparison of the abdomen with the color spectra (RGB, red, green and blue) by two-way ANOVA; the first factor is the sex and the second is sexual maturity. DF = degrees of freedom, MS mean square, $F=F$ test value, $*=P<0.0125$ (Bonferroni correction).

\begin{tabular}{|c|c|c|c|c|c|}
\hline & \multirow{2}{*}{ Factors } & \multicolumn{4}{|c|}{ Abdomen } \\
\hline & & DF & MS & $F$ & $P$ \\
\hline \multirow{3}{*}{$\underset{\mho}{\mathscr{\vartheta}}$} & Sex & 1 & 608.5 & 2.291 & 0.1311 \\
\hline & Maturity & 1 & 612.1 & 2.304 & 0.1300 \\
\hline & Sex x Maturity & 1 & 4824.3 & 18.163 & $0.0000^{*}$ \\
\hline \multirow{3}{*}{$\begin{array}{l}\underset{d}{\simeq} \\
\approx\end{array}$} & Sex & 1 & 153.0 & 0.624 & 0.4302 \\
\hline & Maturity & 1 & 2191.6 & 8.937 & $0.0030 *$ \\
\hline & Sex x Maturity & 1 & 1960.1 & 7.993 & $0.0050 *$ \\
\hline \multirow{3}{*}{$\begin{array}{l}\overline{0} \\
\stackrel{0}{0} \\
\dot{0}\end{array}$} & Sex & 1 & 641.8 & 2.261 & 0.1337 \\
\hline & Maturity & 1 & 682.6 & 2.404 & 0.1220 \\
\hline & Sex x Maturity & 1 & 4982.4 & 17.550 & $0.0000 *$ \\
\hline \multirow{3}{*}{ 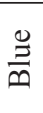 } & Sex & 1 & 4127.2 & 13.494 & $0.0002 *$ \\
\hline & Maturity & 1 & 34.2 & 0.112 & 0.7381 \\
\hline & Sex x Maturity & 1 & 7949.1 & 25.990 & $0.0000 *$ \\
\hline
\end{tabular}

Crabs usually show intraspecific and/or interspecific aggressive behavior (Warner 1970, Innocenti et al. 2003, Tavares and Mendonça 2011). The color variation related to the individuals' size found in this study may indicate dominance among individuals for resources such as food or location, and mating for males. Aggressive behavior may be one of the reasons for the large number of mutilated individuals of C. hellerii reported by Sant'Anna et al. (2012b) and the probable effect on the local population of the red swimming crab Cronius ruber (Lamarck 1818) at São Vicente Island, Brazil, where the native population of $C$. ruber has decreased considerably (Sant'Anna et al. 2012b). This behavior could be related to these color morphotypes as one of the factors to determine the outcome of intraspecific competition for resources, as widely described for $U c a$ spp., since there was wide color variation among the larger individuals of $C$. hellerii.

Some crabs have daily cycles of color variation, related to the tidal cycle or the day and night periods (Fingerman 1955, Fingerman and Aoto 1962, Darnell 2012). Many crabs also show rapid color changes due to stress situations, predation, or temperature, and the color changes in semiterrestrial crabs are more intense (Hemmi et al. 2006, Detto et al. 2008, Silbiger and Munguia 2008). In portunid crabs these color changes are not as intense, at least for juveniles of the blue crab Callinectes sapidus (Rathbun 1896) (Fingerman 1955). The juveniles of C. hellerii showed a predominance of darker color, with no visible changes as they were transported to the laboratory. This initially dark color may be due to predation pressure, since they could be targeted by larger conspecific individuals. The dark-colored rocks make these darker $C$. hellerii more difficult to observe, as recorded for $C$. annulata (Trivedi and Vachhrajani 2012). The estuary water could provide further camouflage, since it absorbs more light (Bricaud et al. 1981, 1998, Doxaran et al. 2006). The dark color might also be a mechanism of UV-protection (Darnell 2012), since these crabs are exposed to high levels of UV radiation while foraging on the rocks of the intertidal zone.

Another finding of this study was the color variation of the female abdomen. This variation found for $C$. hellerii suggests that the abdomen color is related to the sexual maturity of the females, which also suggests that it would be possible to know when the female is about to become an 

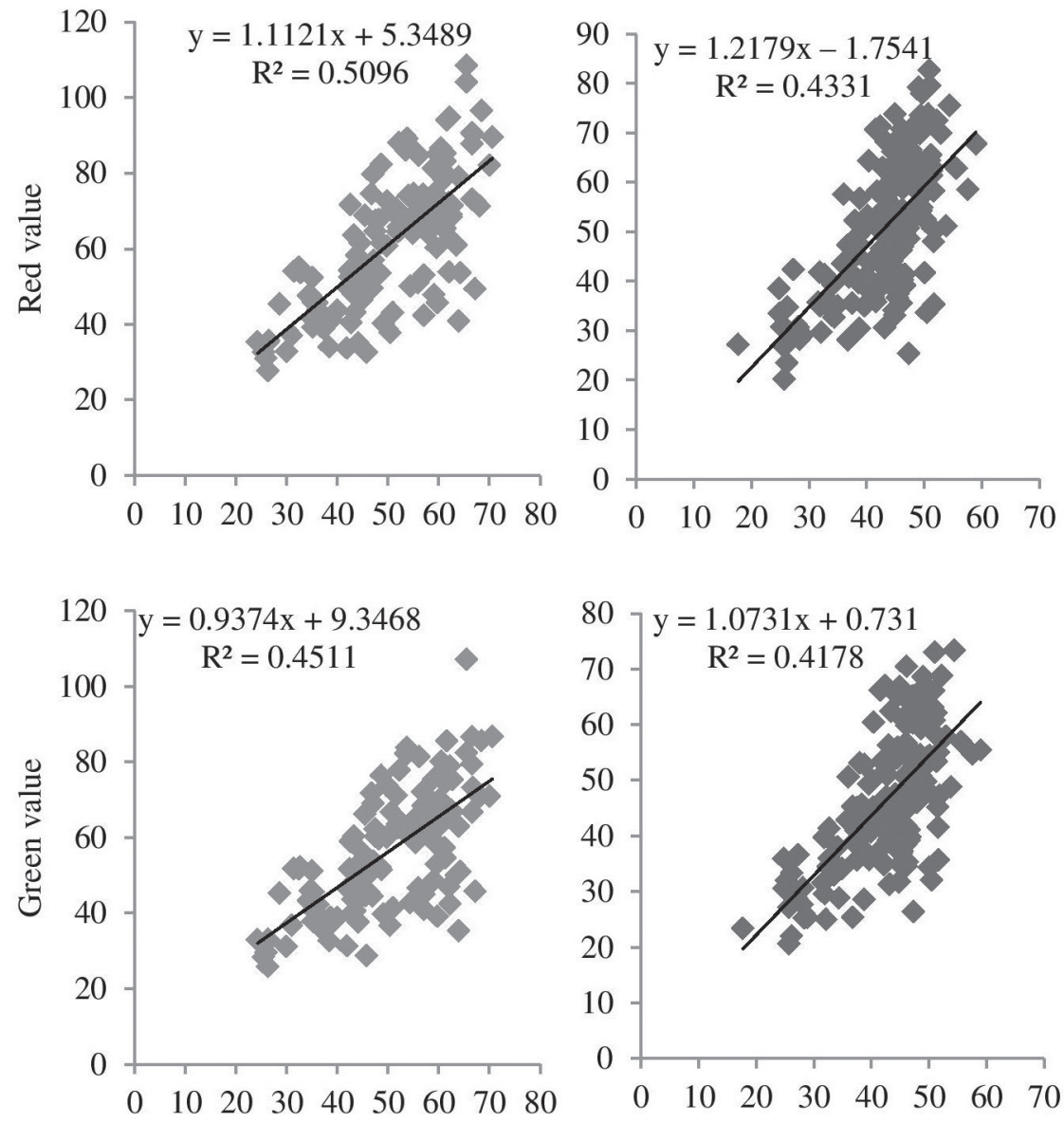

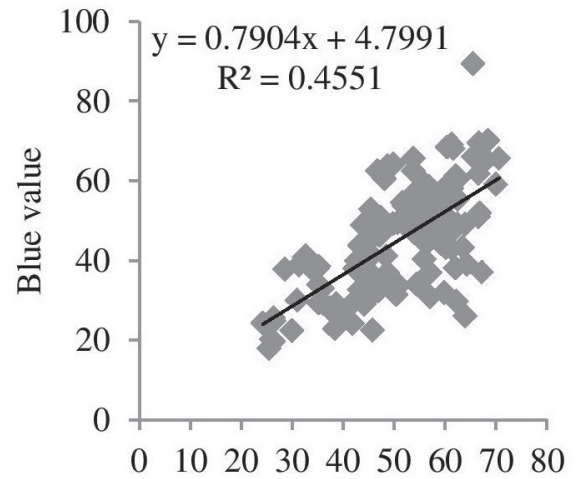

Carapace Width (mm)

Males

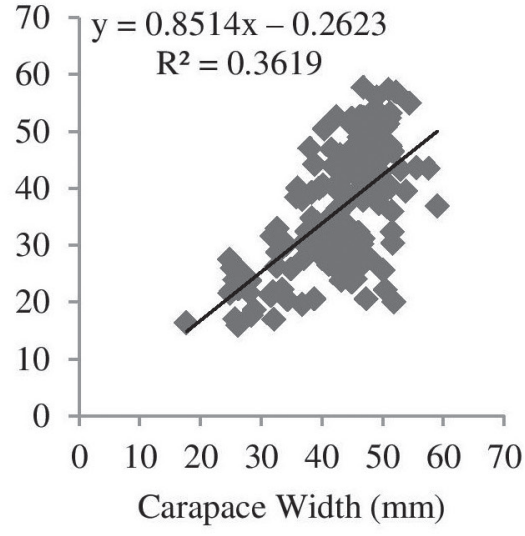

Females

Figure 4 - Relationship between the values of carapace color spectra and carapace size for males and females of Charybdis hellerii. Values of $F$ test: $\left(F_{\operatorname{Red}(m)}=139.2371, \mathrm{DF}=1\right.$, $P<0.0001 ; F_{\text {red }(f)}=128.3680, \mathrm{DF}=1, P<0.0001 ; F_{\text {green }(m)}=110.1261, \mathrm{DF}=1, P<0.0001 ; F_{\text {green }(f)}=$ $120.5425, \mathrm{DF}=1, P<0.0001 ; F_{\text {blue }(m)}=111.8956, \mathrm{DF}=1, P<0.0001 ; F_{\text {blue }(f)}=95.2872, \mathrm{DF}=1$, $P<0.0001)$. Alpha value after Bonferroni correction $P=0.0125$. 

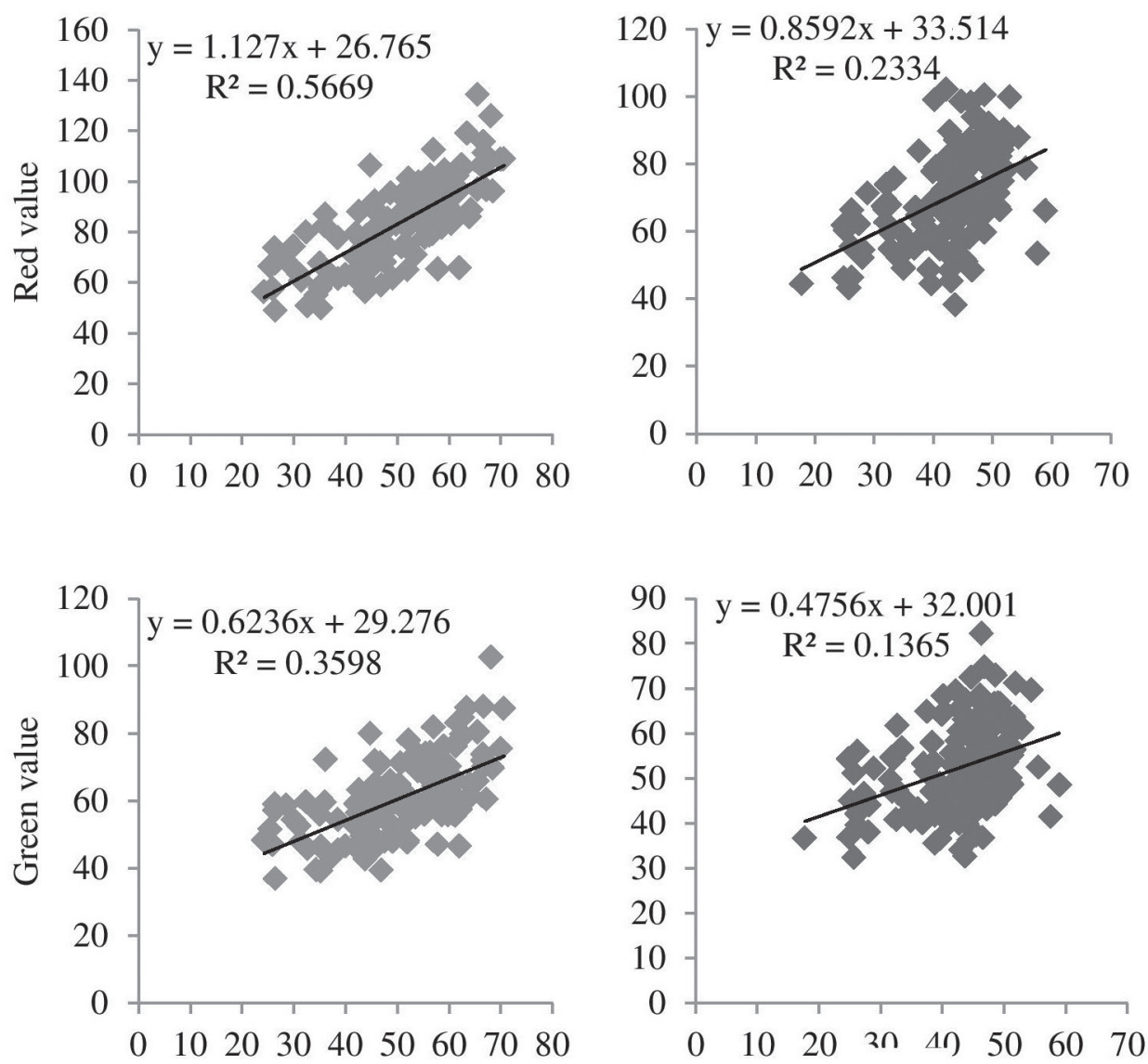

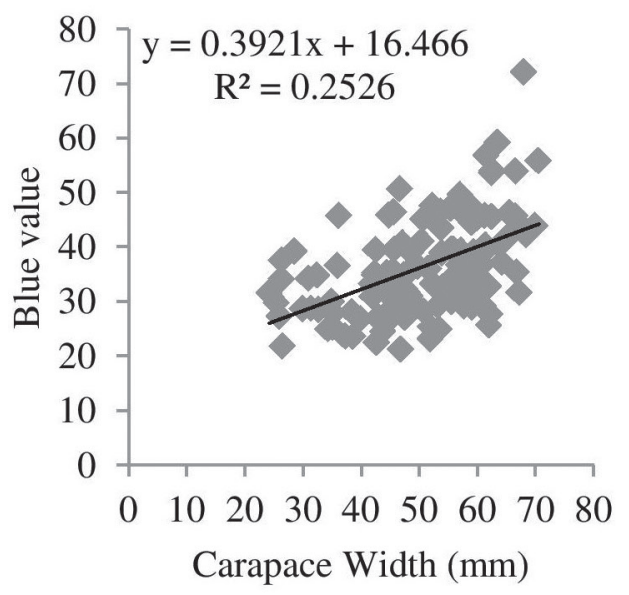

Males

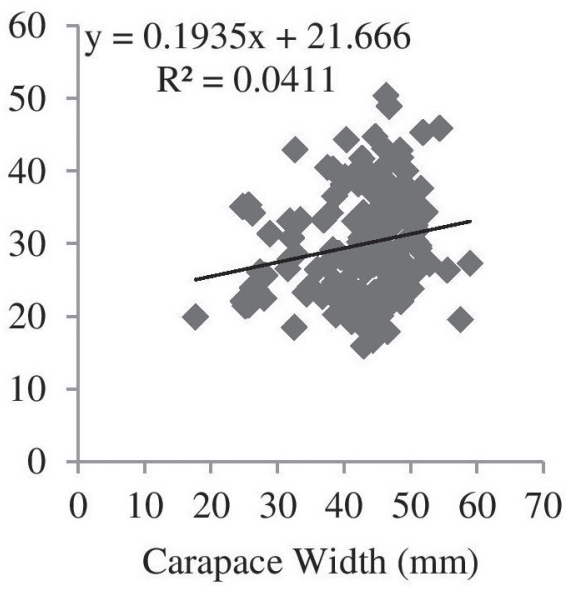

Females

Figure 5 - Relationship between cheliped (external) colors and size for both males and females of Charybdis hellerii (, DF=1, $P<0.0001 ; F_{\text {red }(m)}=159.6649, \mathrm{DF}=1, P<0.0001 ; F_{\text {red(f) }}=45.3566, \mathrm{DF}=1$, $P<0.0001 ; F_{\text {green }(m)}=68.5695, \mathrm{DF}=1, P<0.0001 ; F_{\text {green }(f)}=23.5528, \mathrm{DF}=1, P<0.0001 ; F_{\text {blue }(m)}=41.2313$, $\left.\mathrm{DF}=1, P<0.0001 ; F_{\text {blue }(f)}=6.3794, \mathrm{DF}=1, P=0.0121\right)$. Alpha value after Bonferroni correction $P=0.0125$. 


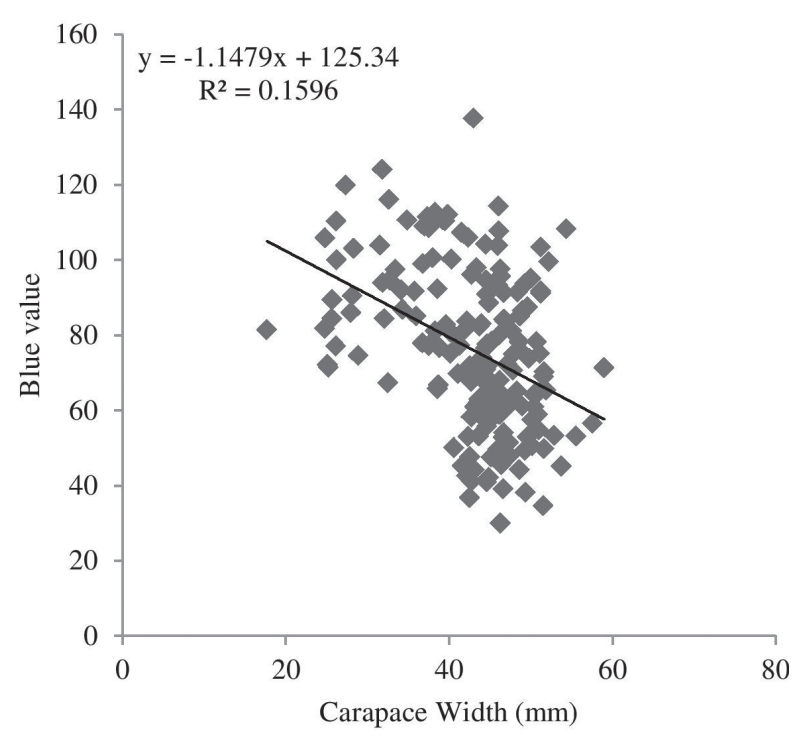

Figure 6 - Relationship between abdomen color values with size of females of Charybdis hellerii. $\left(F_{\text {bluef } f}=31.9055\right.$, $\mathrm{DF}=1, P<0.0001$; the other color spectra showed no statistical difference). Alpha value after Bonferroni correction $P=0.0125$.

adult, as recorded for $A$. cribanarius, with a possible relationship to physiological maturity (Pinheiro and Taddei 2000). However, no relationship between color and physiological maturity was found for $U$. cordatus (Castilho et al. 2011). It is also possible that adult individuals (of both sexes) could perceive whether an individual is sexually mature, since there was a difference in the green and red color wavelengths, which would provide another way of organizing the population. For researchers, this could also be helpful in future studies of behavior, since it would not be necessary to dissect and/or remove individuals from nature to determine their sexual maturity (Costa and Negreiros-Fransozo 1998).

According to Casariego et al. (2011), the crab color was associated with the length of the intermolt period. The European green crab Carcinus maenas (Linnaeus 1758) shows two color morphotypes: green is associated with periods when they grow rapidly and molt frequently, whereas large crabs with an extended intermolt period and consequently an older exoskeleton are darker red. The red-colored crabs have low physiological tolerance (Styrishave et al. 2004). The color variation with size observed here in $C$. hellerii, specifically in the juvenile and adult phases, could be associated with a change in growth and reproductive condition.

There was also a relationship between the size of $C$. hellerii and the red and green colors of the carapace and the external portion of the chelipeds. The difference in color between adult males and females might indicate some value for territorial disputes or mate choice, as suggested for Callinectes spp. (Baldwin and Johnsen 2012). The color of male chelipeds can be important for brachyuran mate choice, as observed in $U$. mjoeberg by Detto (2007), who described the role of color vision in mate choice. A similar situation also occurs in $C$. hellerii, with the different color at the onset of sexual maturity, mainly in females in which the color changes were related to the morphological transition from juveniles to adults associated with sexual maturation. Although visual differences between sexes related to size occur in C. hellerii, they may be a secondary signal in the mating behavior, as described for C. sapidus, where the pheromones are more important than the visual signals (Gleeson 1980).

Digital images are increasingly important in science, and researchers are using this tool to test hypotheses in different fields such as medical measurements (Blauth et al. 1990), biomedical research (Zhang and Arola 2004), and remote sensing of sea water (Forster et al. 1993), among others. Some of them have used the widely known software Adobe Photoshop to acquire the RGB color values, provided by the program histogram (Casariego et al. 2011, Singh et al. 2011). Although this software is renowned, its license is costly, especially for users in developing countries. The results found here comparing Adobe Photoshop and the free software GIMP showed that the two performed comparably; GIMP is a less expensive tool that can be used for studies involving color assessments. The high cost of some tools has 
stimulated researchers to use their creativity to solve cost problems. A spectrophotometer is an expensive equipment for analytical chemistry and not all laboratories have sufficient resources to afford one. This problem might be resolved by the use of digital image analysis, which could produce reliable results and is less expensive than a spectrophotometer (Gaiao et al. 2006, Lyra et al. 2009).

The results of this study revealed that $C$. hellerii shows color differences regarding sexual maturity for both sexes. In particular, the female abdomen undergoes both morphological and color changes related to physiological sexual maturity. As the body size increases, the red and green spectra also increase. These color variations may be associated with intraspecific relationships. We provide another perspective on the method of digital image analysis, in that the freeware program showed the same efficiency as a widely known commercial program, and could prove to be a less-expensive method for color evaluation.

\section{ACKNOWLEDGMENTS}

The authors thank the Coordenação de Aperfeiçoamento de Pessoal de Nível Superior (CAPES) (TTW) for scholarship grants, and the Conselho Nacional de Desenvolvimento Científico e Tecnológico (CNPq) (grants \#301240/2006-0; \#308215/2010-9) (AT and FJZ respectively). FJZ also thanks the Fundação de Amparo à Pesquisa do Estado de São Paulo (FAPESP \#2005/04707-5 and \#2010/50188-8). The authors acknowledge Dr. Marcos H. Toyama for allowing the use of facilities at the UNESP-CLP campus during the research, and Marcelo A.A. Pinheiro, Douglas Vigliazzi and Wagner Villano for providing technical support at UNESP-CLP. We also thank Dr. Janet W. Reid (JWR Associates) for revising the English text.

\section{RESUMO}

Invasões biológicas marinhas são processos naturais acelerados pelas atividades humanas e o siri Charybdis hellerii é um exemplo de espécies invasoras distribuídas pelo mundo. Este estudo avaliou a variação de cor em $C$. hellerii e sua relação com o sexo, tamanho e maturidade sexual desses indivíduos, e comparou a eficiência de um programa de edição de imagem de licença livre com um programa disponível comercialmente. A cor dos indivíduos foi analisada usando imagem digital padronizada. O padrão de cor variou significantemente com o tamanho; indivíduos pequenos e imaturos são mais escuros que indivíduos maiores e maduros. Os abdomens das fêmeas mudaram morfologicamente e na cor de acordo com a maturidade sexual, tornandose mais largos e de cor alaranjada. Não houve diferença estatística nos valores de cor entre machos e fêmeas, e machos imaturos não mostraram diferenças morfológicas e de cor em seus abdomens. Este estudo ressalta as possíveis relações da cor e estado fisiológico do sistema reprodutivo o que pode ajudar futuramente em estudos comportamentais, evitando a necessidade de dissecar e/ou remover indivíduos da natureza para avaliar a maturidade sexual. O programa livre obteve a mesma eficiência na análise de imagem digital em relação ao programa comercial amplamente conhecido.

Palavras-chave: Brachyura, variação de cor, imagem digital, Portunidae.

\section{REFERENCES}

ABDI H. 2007. Bonferroni and Šidák corrections for multiple comparisons. In: Salkind NJ (Ed), Encyclopedia of Measurement and Statistics. Thousand Oaks, CA: Sage.

ABele LG, CAmpanella PJ AND SALMON M. 1986. Natural history and social organization of the semiterrestrial grapsid crab Pachygrapsus transversus (Gibbes). J Exp Mar Biol Ecol 104: 153-170.

Aguilar R, Hines AH, Wolcott TG, Wolcott DL, KRAMER MA AND LIPCIUS RN. 2005. The timing and route of movement and migration of post-copulatory female blue crabs, Callinectes sapidus Rathbun, from the upper Chesapeake Bay. J Exp Mar Biol Ecol 319: 117-128.

BALDWIN J AND JOHNSEN S. 2012. The male blue crab, Callinectes sapidus, uses both chromatic and achromatic cues during mate choice. J Exp Biol 215: 1184-1191.

Blauth CI, Smith PL, ARnold JV, Jagoe JR, Wootton R AND TAYLOR KM. 1990. Influence of oxygenator type on the prevalence and extent of microembolic retinal ischemia during cardiopulmonary bypass. Assessment by digital image analysis. J Thorac Cardiov Sur 99: 61-69. 
Bricaud A, Morel A, Babin M, Allali K and Claustre H. 1998. Variation of light absorption by suspended particles with chlorophyll a concentration in oceanic (case 1) waters: Analysis and implications for bio-optical models. J Geophys Res 103: 31033-31044.

BricAud A, MOREL A AND PRIEUR L. 1981. Absorption by dissolved organic matter of the sea (yellow substance) in the UV and visible domains. Limnol Oceanogr 26:43-53.

CASARIEGO AM, LUPPI T AND IRIBARNE O. 2011. Differential coloration patterns in the intertidal crab Neohelice (=Chasmagnathus) granulata. J Mar Biol Assoc UK 91: 1041-1047.

Castilho GG, Ostrensky A, Pie MR And Boeger WA. 2011. Phenotypical traits and gonadal development in mangrove land crab, Ucides cordatus (Decapoda: Ocypodidae). Acta Zool 92: 393-397.

CHRISTY JH AND SALMON M. 1984. Ecology and evolution of mating systems of fiddler crabs (Genus $U c a$ ). Biol Rev 59: 483-509.

ClARKE GL AND JAMES HR. 1939. Laboratory Analysis of the Selective Absorption of Light by Sea Water. J Opt Soc Am 29: 43-55.

Costa TM AND Negreiros-Fransozo ML. 1998. The reproductive cycle of Callinectes danae Smith, 1869 (Decapoda, Portunidae) in the Ubatuba region, Brazil. Crustaceana 71: 615-627.

CRANE J. 1966. Combat, display and ritualization in fiddler crabs (Ocypodidae, genus Uca). Phil Trans R Soc B 251: 459-472.

CRONING TW AND FoRWARD Jr RB. 1988. The visual pigments of crabs. J Comp Physiol A 162: 463-478.

DARNELL MZ. 2012. Ecological physiology of the circadian pigmentation rhythm in the fiddler crab Uca panacea. $\mathrm{J}$ Exp Mar Biol Ecol 426-427: 39-47.

DetTo T. 2007. The fiddler crab Uca mjoebergi uses colour vision in mate choice. Proc R Soc B 274: 2785-2790.

DetTo T, Hemmi JM AND BACKWELL PRY. 2008. Coloration and colour changes of the fiddler crab, Uca capricornis. A descriptive study. PLOS ONE 3: e1629, 10 p.

Detto T, Zeil J, Magrath RD and Hunt S. 2004. Sex, size and colour in a semi-terrestrial crab, Heloecius cordiformis (H. Milne Edwards, 1837). J Exp Mar Biol Ecol 302: 1-15.

DineEn JF, Clark PF, Hines AH, ReEd SA AND Walton HP. 2001. Life history, larval description, and natural history of Charybdis hellerii (Decapoda, Brachyura, Portunidae), an invasive crab in the western Atlantic. J Crust Biol 21: 774-805

Doxaran D, Cherukuru N AND LaVEnder SJ. 2006. Apparent and inherent optical properties of turbid estuarine waters: measurements, empirical quantification relationships and modeling. Appl Optics 45: 2310-2324.

Fingerman M. 1955. Persistent daily and tidal rhythms of color change in Callinectes sapidus. Biol Bull 109: 255-264.

FINGERMAN M AND AOTO T. 1962. Hormonal Regulation of pigmentary effectors in crustaceans. Gen Comp Endocr S1: 81-93.
ForSTER BC, XINGWEI S AND BAIDE X. 1993. Remote sensing of sea water quality parameters using Landsat-TM. Int J Remote Sens 14: 2759-2771.

Gaiao EN, Martins VL, Lyra WS, Almeida LF, Silva EC AND ARAÚJO MCU. 2006. Digital image-based titrations. Anal Chim Acta 570: 283-290.

GLEESON RA. 1980. Pheromone Communication in the Reproductive Behavior of the Blue Crab, Callinectes sapidus. Mar Behav Phy 7: 119-134.

Hemmi JM, Marshall J, Pix W, VorobyeV M and ZeIL J. 2006. The variable colours of the fiddler crab Uca vomeris and their relation to background and predation. J Exp Biol 209: 4140-4153.

HultGren KM AND Stachowicz JJ. 2008. Alternative camouflage strategies mediate predation risk among closely related co-occurring kelp crabs. Oecologia 155: 519-528.

INNOCENTI G, PINTER N AND GALIL BS. 2003. Observations on the agonistic behavior of the swimming crab Charybdis longicollis Leene infected by the rhizocephalan barnacle Heterosaccus dollfusi Boschma. Can J Zool 81: 173-176.

Karplus I, Hulata G, Ovadia D and Jaffe R. 1992. Social control of growth in Macrobrachium rosenbergii. III. The role of claws in bull-runt interactions. Aquaculture 105: 281-296.

KENNEDY VS AND CRONIN LE. 2007. The blue crab: Callinectes sapidus. Maryland Sea Grant College, University of Maryland, $774 \mathrm{p}$.

Kerckhof F, Haelters J AND Gollasch S. 2007. Alien species in the marine and brackish ecosystem: the situation in Belgian waters. Aquat Invasions 2: 243-257.

Kuris AM, RA'ANAN Z, SAgi A AND COHEN D. 1987. Morphotypic differentiation of male Malaysian giant prawns, Macrobrachium rosenbergii. J Crust Biol 7: 219-237.

LAUfer H, SAgi A AND Ahl JSB. 1994. Alternate mating strategies of polymorphic males of Libinia emarginata appear to depend on methyl farnesoate. Invertebr Reprod Dev 26: 41-44.

Lemaitre R. 1995. Charybdis Hellerii (Milne Edwards, 1867), a nonindigenous portunid crab system of florida. Proc Biol Soc Wash 108: 643-648.

Lyra WS, SANTOS VB, Dionízio AGG, Martins VL, Almeida LF, Gaĩ̃o EN, Diniz PHGD, Silva EC AND ARAÚJO MCU. 2009. Digital image-based flame emission spectrometry. Talanta 77: 1584-1589.

MoRAES-RiodAdes PMCAND VALENTI VC. 2004. Morphotypes in male Amazon River Prawns, Macrobrachium amazonicum. Aquaculture 236: 297-307.

Morel A. 1974. Optical Properties of Pure Water and Sea Water I. In: Gerlov NG and Steemann-Nielsen E (Eds), Optical Aspects of Oceanography. New York, NY: Academic Press.

PINHEIRO MAA AND TADDEI FG. 2000. Chromatic alteration in Arenaeus cribrarius (Lamarck) (Crustacea, Portunidae): an indicator of sexual maturity. Rev Bras Zool 17: 945-951. 
ReID DG, ABelló P, KAiser MJ AND WARMAn CG. 1997. Carapace colour, inter-moult duration and the behavioural and physiological ecology of the shore crab Carcinus maenas. Estuar Coast Shelf S 44: 203-211.

Ruiz GM, Carlton JT, Grosholz ED AND Hines AH. 1997. Global invasions of marine and estuarine habitats by non-indigenous species: mechanisms, extent and consequences. Am Zool 37: 621-632.

SANT'ANNA BS, TURRA A AND ZARA FJ. 2012a. Reproductive migration and population dynamics of the blue crab Callinectes danae in an estuary in southeastern Brazil. Mar Biol Res 8: 354-362.

SANT'ANNA BS, WATANABE TT, TURRA A AND ZARA FJ. 2012b. Relative abundance and population biology of the non-indigenous crab Charybdis hellerii (Crustacea: Brachyura: Portunidae) in a southwestern Atlantic estuary-bay complex. Aquat Invasions 7: 347-356.

Silbiger N AND MunguiA P. 2008. Carapace color change in Uca pugilator as a response to temperature. J Exp Mar Biol Ecol 355: 41-46.

SINGH S, DHYANI D, YADAV AK AND RAJKUMAR S. 2011. Flower colour variations in gerbera (Gerbera jamesonii) population using image analysis. Indian J Agr Sci 81: 1130-1136

SMIth SG AND CHANG ES. 2007. "Molting and growth." The blue crab Callinectes sapidus. In: Kennedy VS and Cronin LE (Eds), The Blue Crab: Callinectes sapidus. Maryland Sea Grant College, University of Maryland, College Park, p. 197-254.

SOKAL RR AND RoHLF FJ. 1995. Biometry: The Principles and Practice of Statistics in Biological Research. New York, NY: W.H. Freeman and Company, 887 p.

STYRISHAVEBAND REWITZKAND ANDERSEN O. 2004. Frequency of moulting by shore crabs Carcinus maenas (L.) changes their colour and their success in mating and physiological performance. J Exp Mar Biol Ecol 313: 317-336.
SulLivan SA. 1963. Experimental Study of the Absorption in Distilled Water, Artificial Sea Water, and Heavy Water in the Visible Region of the Spectrum. J Opt Soc Am 53: 962-968.

TAVARES M AND MENDONÇA Jr JB. 2011. The occurrence of the Indo-Pacific swimming crab Scylla serrata (Forskål, 1775 ) in the Southwestern Atlantic (Crustacea: Brachyura: Portunidae). Aquat Invasions 6: S49-S51.

TRIVEDI JN AND VACHHRAJANI KD. 2012. New record of color morphs of brachyuran crab Charybdis annulata Fabricius, 1798 (Decapoda: Portunidae). Arthropods 1: 129-135.

UNDERWOOD AJ. 1997. Experiments in Ecology: Their logical design and interpretation using analysis of variance. Cambridge: Cambridge University Press, 522 p.

VANNINI M AND INNOCENTI G. 1999. Research on the coast of Somalia. Portunidae (Crustacea Brachyura). Trop Zool 13: 251-298.

VitousEK PM, MOONEY HA, LUBCHENCO J AND MELILLO JM. 1997. Human domination of earth's ecosystems. Science 277: 494-499.

WARNER GF. 1970. Behavior of two species of grapsid crab during intraspecific encounters. Behavior 36: 9-19.

WeE DPC AND NG PKL. 1995. Swimming crabs of the genera Charybdis De Haan, 1833, and Thalamita Latreille, 1829 (Crustacea: Decapoda: Brachyura: Portunidae) from Peninsular Malaysia and Singapore. Raffles Bull Zool 43: 1-128.

YOKES B AND GALIL BS. 2006. New records of alien decapods (Crustacea) from the Mediterranean coast of Turkey, with a description of a new palaemonid species. Zoosystema 28: 747-755

ZHANG D AND AROLA DD. 2004. Applications of digital image correlation to biological tissues. J Biomed Opt 9: 691-699. 